\title{
Post-dipping in Milk Production, Composition, and Quality
}

\author{
Elizabeth Simões do Amaral Alves ${ }^{a}$, João Manoel da Silva ${ }^{b^{*}}$, \\ Micheline Thais dos Santos ${ }^{a}$, Yamina Coentro Montaldo ${ }^{c}$,

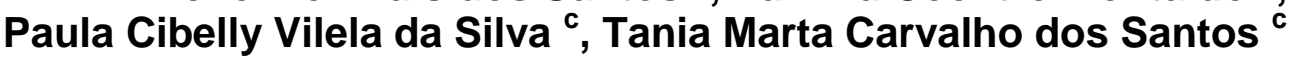 \\ and Elizabeth Sampaio de Medeiros ${ }^{a}$
}

${ }^{a}$ Department of Animal Morphology and Physiology, Veterinarian, Universidade Federal Rural de Pernambuco, Pernambuco, Brazil

${ }^{b}$ Universidade Estadual do Piauí, Campus Jesualdo Cavalcanti, Piauí, Brazil.

${ }^{c}$ Universidade Federal de Alagoas, Engeenering and Agrarian Sciences Campus, Laboratory of Agricultural Microbiology, Alagoas, Brazil.

\begin{abstract}
Authors' contributions
This work was carried out in collaboration among all authors. All authors read and approved the final manuscript.

Article Information

DOI: 10.9734/ARRB/2021/v36i1230461 Editor(s):

(1) Dr. Saleha Sadeeqa, Lahore College for Women University, Pakistan. Reviewers:

(1) Elhassan Benyagoub, University of Bechar, Algeria. (2) Vikas Pahal, Dolphin (PG) College of Science and Agriculture, India. Complete Peer review History, details of the editor(s), Reviewers and additional Reviewers are available here: https://www.sdiarticle5.com/review-history/77298
\end{abstract}

Original Research Article

Received 27 September 2021

Accepted 01 December 2021

Published 13 December 2021

\section{ABSTRACT}

This study aimed to evaluate the influence of post-dipping on milk production, composition, and quality of cows with subclinical mastitis. Samples of mast milk from two different dairy farms were analyzed in two moments: before the post-dipping implantation and after 30 days, the samples were conditioned to the refrigeration temperature in an isothermal box and sent to the laboratory for the following analyzes: California Mastitis Test (CMT), Somatic Cell Count (SCC), Fat, Protein, Lactose, Total Solids (TS), Non-Fat Solids (NFS) and microbiological tests, as well as individual milk weighing. The experimental design was completely randomized and arranged in a split-plot scheme, submitted to analysis of variance (ANOVA) by the F test. The post-dipping practice during 30 days resulted in the means and standard deviation of the analyzes of the studied variables, where the values of SCC, CMT, and microbiological score profile were statistically significant. The 
highest etiological agent found was Staphylococcus spp. The fat and lactose profile increased in both farms, but there was no significant difference. Protein increased in both farms, but in farm I, there was no significant difference and in farm 2, there was a significant difference. Total Solids, Non-greasy solids, and weighing had a percentage increase, but the means of weight did not differ statistically. The post-dipping technique was an effective measure in the control of subclinical mastitis and brings health benefits to the mammary gland.

Keywords: Animal health; somatic cell; subclinical mastitis; Staphylococcus spp.

\section{INTRODUCTION}

Bovine mastitis is a health problem that affects dairy cattle around the world. It consists of an inflammatory process of the mammary gland, usually infectious caused by different etiological agents mainly by bacteria. Depending on its manifestation, this disease can be classified as clinically (with udder inflammation and macroscopic abnormalities in milk) or subclinical (with no visible changes in the udder and milk) and based on he type of pathogen, such as contagious or environmental [1].

Subclinical mastitis can be diagnosed by the California Mastitis Test (CMT) and by laboratory tests that detect milk somatic cell count (SCC), milk from mast cells has high SCC, and a large industrial scale loss due to problems in the production of derivatives [2]. In addition, they can manifest in the function of failures in the animals' management [3]

Post-dipping is one of the most effective measures of control of subclinical mastitis, which consists in the application of an antimicrobial agent, to disinfect and protect the ceilings, after milking, of the possible action of microorganisms from the external environment such as the microbiota of the animal's skin.

A good post-dipping procedure uses an effective disinfectant, preventing the colonization of the roof canal by contagious pathogens, immediately after milking, allowing the entire surface to be immersed using an applicator cup [4].

The focus on the quality of milk as raw material refers mainly to its inference on the quality of industrial products and the pre-eminent risk to public health. Measurement of this quality is done by measuring fat and protein levels, sensory quality, number of bacteria, and somatic cell count [5].

Considering that most mastitis is acquired during milking, through the hands of the milker, utensils, and from one animal to another, this study aimed to evaluate the influence of post-dipping on the production, chemical composition, and quality of milk seen which is a simple low-cost method of mastitis control that works to protect the roof of contagious agents during milking, maintaining the health of the mammary gland and consequently increasing the efficiency of milk production.

\section{MATERIALS AND METHODS}

The study was developed in two dairy farms: a farm located in Craíbas, a municipality located in the central region of Alagoas, Brazil and, the other dairy farm located in Camaragibe, a municipality in the metropolitan region of Recife in the state of Pernambuco, Brazil. The herds were composed of animals of various races, ages and, that are in different stages of lactation. Created in a semi-intensive system and manual milking. On the farms, no disinfectant was used to sanitize the ceilings. Animals diagnosed with subclinical mastitis were used in the experiment.

The assay consisted of data collection in two moments: the time I, before the hygienic management of the milking was implemented, where the post-dipping technique was not used as a control program. Time II, after training and implantation of the hygienic management of the milking, practiced the post-dipping with the use of iodine-based disinfectant, in the concentration of $0.5 \%$.

The test of the dark bottom mug and the CMT in the dairy herd were performed. To perform the segregation of the animals with subclinical mastitis, those that fit the CMT positive from two crosses (++) were carefully chosen, and these were used in the experiment, thus totaling 61 animals, 30 of the state of Pernambuco and 31 of the state of Alagoas, both from Brazilian northeastern.

The milk secretions of these animals were analyzed and the milk was weighed from the pail to measure the production before and after the 
use of the post-dipping technique. The analyzes were: Somatic Cell Count (SCC), Fat, Protein, Lactose, Total Solids (TS), Non-Fat milk Solids (NFS) and microbiological tests performed at the time I and II.

The training was carried out with the milkers, on the management of milking, on the use of the post-dipping practice, on the hygiene of utensils and milkers, with the use of a didactic poster to illustrate the practice of post-dipping.

From the identification of the positive for subclinical mastitis, the milking line was implanted and post-dipping was used: $1^{\text {st }}$ ) firstcalf heifer; $2^{\text {nd }}$ ) cows that never had mastitis; $3^{\text {rd }}$ ) cows that had clinical mastitis for more than six months; $4^{\text {th }}$ ) cows that had clinical mastitis in the last six months. Cows with clinical mastitis were separated from the herd.

The disinfection of the ceilings through postdipping was performed by the complete immersion method in $0.5 \%$ commercial iodine solution, for the application was used the mugs of the one-way model, which prevents the disinfectant administered in the ceiling do not mix with mug solution after application.

Thus, a 30-day period was adopted with the use of the disinfectant solution in these 61 animals with subclinical mastitis. During this period, 244 samples of milk secretions from the mammary quarters and 61 samples of the animals were collected to repeat the analyzes for the posterior comparison.

From the 61 animals, 244 bovine milk samples from mammary quarters were analyzed for microbiological analysis before milking and, 61 samples of bovine milk after finishing milking for the analysis of SCC, Fat, Protein, Lactose, TS, and NFS.

Thus, before milking the milk samples from the mammary quarters were collected after previous washing of the ceiling with soap and water, drying with a paper towel, and antisepsis of the ceiling ostium with alcohol at $70 \%$. In continuity, a volume of $10 \mathrm{ml}$ was obtained, in bottles with screw-cap, sterilized, and previously identified with the name or number of the animal as well as the corresponding mammary room. These samples were conditioned to the refrigeration temperature in an isothermal box with refrigeration and sent to the Microbiology laboratory for processing.
A $0.1 \mathrm{ml}$ aliquot was seeded on base agar plus $10 \%$ defibrinated sheep blood culture medium. The plates were incubated at $37{ }^{\circ} \mathrm{C}$ in a microbiological stove, and the readings were performed after 24 hours. The isolated agents were identified according to the morphological characteristics of their colonies, such as size, type, staining, and presence of hemolysis [6]. Under the microscope, the cell layout and the morphotinatory characteristics of the Gram technique were observed.

The milk was homogenized from the bucket with the aid of a previously cleaned stainless steel shell, in this way the milk was transferred to the collection flask. The vials contained a bronopol pellet and the milk volume was gently homogenized several times until the pellet was completely dissolved. Being properly sent to the laboratory of PROGENE in the Department of Animal Science of the Federal Rural University of Pernambuco, in isothermal boxes. The SCC and chemical composition of the milk was determined by the flow cytometry technique.

The experimental design was completely randomized and arranged in plots subdivided in time, two collections corresponding to the plots, and two farms the subplots. The collected data were submitted to analysis of variance (ANOVA) by the $\mathrm{F}$ test $(P \leq 0.05)$ in the software Sisvar 5.6 [7].

\section{RESULTS AND DISCUSSION}

The results of the means and standard deviation of the analyzes of a total of 305 milk samples from two farms were studied, evaluating the effect of post-dipping on the variables studied: SCC, CMT, Fat, Protein, Lactose, Total Solids, Non-Fat Solids NFS), weighing $(\mathrm{kg})$ and microbiological yield, in two stages, before and after the implementation of the post-dipping practice.

In farm I, the SCC values that the milk presented before the implantation of the post-dipping, was an average of $251,443 \mathrm{cells} / \mathrm{ml}$, the ranch II presented an average of $778,060 \mathrm{cells} / \mathrm{ml}$, these values do not correspond to the limits recommended by the Normative Instruction 76 (NI76) [8], which establishes a maximum value of 400,000 cells $/ \mathrm{ml}$. After the 30 days using commercial iodine disinfectant at $(0.5 \%)$ postdipping, it was possible to observe a reduction in farm I of $45.75 \%$ and in farm II of $46.03 \%$, where the farm II was included in the NI76, which is a 
significant reduction, revealing that the data obtained in this work demonstrate the postdipping as an efficient and simple method for the control of subclinical mastitis, as expressed in Table 1.

The milk from farm I, which decreased to $115,056 \mathrm{cell} / \mathrm{s} / \mathrm{ml}$, indicates significant recovery of production because higher values of SCC present lower manufacturing yield and texture defects in cheese processing due to increased coagulation time, lower clot firmness, and loss of solids from the milk to the serum, supported by the study of Coelho [9], who studied the effect of somatic cell counts on the yield and physicochemical composition of the mussarella cheese, where they state that the somatic cell count SCC of milk is an important parameter for the whole dairy chain since it favors modifications in the raw material due to the occurrence of subclinical mastitis.

The high values of SCC found in the study are an alert for milk adulteration tests since these milk have higher than normal levels of chlorides and can thus result in a false-positive result, assuming milk fraud by the addition of chloride sodium, for example, by Zanlorenzi and Montanhini [10] in their study on the Investigation of adulteration of milk, by the efficiency of the qualitative test of chlorides, affirm that the milk chloride from cows with subclinical mastitis should be used cautiously, because kinds of milk with high SCC, contained levels of chlorides above normal.

The evaluation of SCC in the study revealed that in farm I, the period of 30 days practicing postdipping was not enough to fit NI76 standards, so Vargas et al. [11] reinforced the importance of SCC as an indirect diagnostic criterion of subclinical mastitis, since, besides being a normative requirement of inspection agencies in Brazil and several other countries in the world, this indicator is related to milk composition, industrial yield, and determination of food safety of the product, while for producers, is an important tool in controlling the health of the mammary gland, quality of the raw material and loss of production.

Microbiological analysis revealed that the etiology of the subclinical mastitis of the two farms was due to two genera of microorganisms, Staphylococcus and Streptococcus. These agents are classified into infectious subclinical mastitis [3,12], where contamination occurs at the moment of milking, mainly by the hand of the milk and utensils. The result obtained shows that the most active agent of the pathology was Staphylococcus spp.

Some samples had microbiological growth for the two genres concomitantly, corresponding to the percentage of $2.50 \%$ of the cases. Staphylococcus spp. which had a percentage of $95.83 \%$ in farm I before the implementation of post-dipping, after 30 days post-dipping reduced its percentage by $11.47 \%$, a statistically significant result. In farm II, before the implantation of post-dipping, Staphylococcus spp. presented a percentage of $73.38 \%$, after use with duration of 30 days there was a $31.86 \%$ reduction in their growth, these results were also significant, making use of post-dipping in the control of subclinical mastitis. The results of the research demonstrate the efficiency of postdipping in the reduction of microbial growth in milk samples after 30 days of application (Table 1).

The CMT score readings obtained in the study reveal that the farm I had a high percentage for readings with three crosses (+++) with $30.83 \%$, this reading is the most worrying in the diagnosis of subclinical mastitis, the use of the post-dipping led to a fall of $70.25 \%$, where $(9.17 \%)$ of the animals came to fit this reading, which was a very significant reduction percentage. For reading two crosses $(++)$ there was a fall of $3.14 \%$ and in reading a cross $(+)$ there was an increase of $5.42 \%$, a satisfactory result since the objective is to make most of the animals fit into readings of lower scores. The trait readings increased from $15.33 \%$ to $22.50 \%$, an increase of $46.77 \%$, a statistically significant result (Table 2).

Farm II presented the percentage of $7.37 \%$ of the animals with reading three crosses (+++) and the use of post-dipping allowed them to fall $100 \%$ in this score, so the animals reduced their degree of manifestation of the disease by presenting only $3.27 \%$ for reading two crosses (++) after post-dipping practice, where the percentage drop was $88.60 \%$, a statistically significant result. In the reading score of a cross (+), there was no significant difference, being represented by the percentage of fall of $3.61 \%$, whereas in the trait readings there was an increase of $37.94 \%$ positive result since the number of animals in this reading. The performance of the disinfectant decreased the percentages that were included in the higher readings increasing the percentage of reading of the lower score (Table 2). 
The CMT on the two farms for the score readings (+) confirmed the situation of subclinical mastitis when a microbiological examination was performed. Santana et al. [13], who investigated cure rates of subclinical mastitis treatment after intramammary infusion of active antimicrobial at the time of drying where they observed that the mammary glands that did not present clinical abnormalities and bacteriologically positive growth had a positive CMT score from a (+) cross, revealing manifestation of the pathology from this CMT score reading.

The CMT assessments in the study demonstrated compliance according to CCS values, However, Braz et al. [14] in their study compared the CMT in dairy cows on Mato Grosso do Sul, Brazil, $75 \%$ were positive in the CMT test, and $35.7 \%$ were PCR positive in $7.1 \%$ of the cases increased CRP without determining CMT positivity, due to the results of their work considered that the CMT leaves doubts as to its interpretation.
After 30 days with post-dipping, the fat percentage of the farms under study increased in farm I there was an increase of $10.51 \%$, but statistically, there was no significant difference and in farm II there was an increase of $16.97 \%$ with a significant difference, as expressed in Table 3. The period of use of post-dipping decreased and controlled the infection of the mammary gland, protecting the canal from the proliferation of microorganisms that attack the glandular epithelium and, alter the production of fat for changing the passage of fat precursors, especially acetate.

The measurement of milk fat in the study showed a higher percentage in farm II, as it obtained a higher percentage of SCC reduction, which implies lower rates of mastitis. The percentage of protein increased after the use of post-dipping, but in farm I that obtained an increase of $4.21 \%$, there was no significant difference and in farm II it was of $12.78 \%$, a very significant difference, as expressed in Table 3.

Table 1. Somatic cell counts and microbiological growth of two farms under study, before and after the use of post-dipping

\begin{tabular}{|c|c|c|c|}
\hline Farm & Collect & SCC1 & Microbiological (\%) \\
\hline \multirow[t]{2}{*}{ I } & 1 & $251.443 \mathrm{a}^{*}$ & $95.83 \mathrm{a}$ \\
\hline & 2 & $115.056 \mathrm{~b}$ & $84.83 \mathrm{~b}$ \\
\hline \multirow[t]{2}{*}{ II } & 1 & $778.060 \mathrm{a}$ & $73.39 \mathrm{a}$ \\
\hline & 2 & $358.160 \mathrm{~b}$ & $50.00 \mathrm{~b}$ \\
\hline
\end{tabular}

Table 2. CMT score profile of two farms under study, before post-dipping implantation and after 30 days with the use of the post-dipping

\begin{tabular}{|c|c|c|c|c|c|}
\hline \multirow[t]{2}{*}{ Farm } & \multicolumn{5}{|c|}{$\mathrm{CMT}^{1}(\%)$} \\
\hline & Collect & Traits & + & ++ & +++ \\
\hline \multirow[t]{2}{*}{ I } & 1 & 15.33 & 21.67 & 26.67 & 30.83 \\
\hline & 2 & 22.50 & 29.17 & 25.83 & 9.17 \\
\hline \multirow[t]{2}{*}{ II } & 1 & 23.77 & 22.13 & 28.69 & 7.37 \\
\hline & 2 & 32.79 & 21.33 & 3.27 & 0.00 \\
\hline
\end{tabular}

Table 3. Chemical composition and milk production of two farms under study, before the implantation of post-dipping and after 30 days

\begin{tabular}{llllllll}
\hline \multicolumn{7}{c}{ Composition (\%) } \\
\hline Farm & Collect & Fat (\%) & $\begin{array}{l}\text { Protein } \\
(\%)\end{array}$ & $\begin{array}{l}\text { Lactose } \\
(\%)\end{array}$ & Solids (\%) & $\begin{array}{l}\text { NFS } \\
(\%)\end{array}$ & $\begin{array}{l}\text { Weighing } \\
(\mathbf{g})\end{array}$ \\
\hline $\mathrm{I}$ & 1 & $5.23 \mathrm{a}^{*}$ & $3.32 \mathrm{a}$ & $4.38 \mathrm{a}$ & $13.48 \mathrm{a}$ & $8.45 \mathrm{a}$ & $4.53 \mathrm{a}$ \\
& 2 & $5.78 \mathrm{a}$ & $3.46 \mathrm{a}$ & $4.45 \mathrm{a}$ & $13.53 \mathrm{a}$ & $8.65 \mathrm{a}$ & $4.91 \mathrm{a}$ \\
$\mathrm{I}$ & 1 & $3.83 \mathrm{a}$ & $3.05 \mathrm{a}$ & $4.59 \mathrm{a}$ & $12.74 \mathrm{a}$ & $8.66 \mathrm{a}$ & $9.31 \mathrm{a}$ \\
& 2 & $4.48 \mathrm{~b}$ & $3.44 \mathrm{~b}$ & $4.67 \mathrm{a}$ & $13.28 \mathrm{a}$ & $9.05 \mathrm{~b}$ & $10.01 \mathrm{a}$ \\
\hline
\end{tabular}

${ }^{*}$ Means followed by the same letter do not differ by the $F$ test $(P \leq 0.05) .{ }^{1}$ Non-Fat milk Solids. 
Protein is a very important component for the dairy industry and is a reward item for the producer, according to the study of Andreatta et al. [15] when studying the evaluation of the yield and proteolysis of cheese Minas Frescal produced with different levels of SCC studies have indicated that mastitis determines changes in protein fractions implying the potential of milk as a raw material for the manufacture of derivatives, especially cheese. since the industrial yield of milk is mainly associated with the fraction of casein that is altered as a result of pathology.

This problem for the highest-paid component for the industry which is protein, directly interferes in the transformation of milk into cheese, since it is necessary to form a curd, this procedure causes the milk casein to coagulate initiating the milk processing into cheese, so it is necessary that the milk protein fractions are not reduced and do not undergo proteolysis action, which occurs when the mastic milk is purchased as raw material.

In the present study, it was observed that there was a percentage growth in lactose component of $1.59 \%$ in farm I and of $1.74 \%$ in farm II after the period of post-dipping use, but these differences were not significant (Table 3). Among all components of milk, lactose is the least variable, which translates into non-significant growth for this component.

The results obtained with the measurement of non-greasy solids show that before the practice of post-dipping the means of farm I was $8.45 \%$ and farm II was $8.66 \%$. After 30 days using the disinfectant, the means had an increase, where the farm I increased $2.36 \%$ and the farm II increased $4.50 \%$, in the farm II or increase was considered statistically significant (Table 3 ).

It was observed that the percentage of increase of total solids in farm I was $0.37 \%$ and in farm II of $4.23 \%$, these increases for both were not statistically significant, after the time of the use of the disinfectant in post-dipping. Total solids are very important to the industry and the milk payment system pays remunerative incentives for total solids, corroborating with Ribas et al. [16] in his research on Total milk solids in tank samples which observed a variation in the total solids concentration in 257.540 samples of milk from tanks and the mean of total solids was $12.37 \%$.

The weight of the milk before the implantation of the use of post-dipping in farm I was an average of $4.53 \mathrm{~kg}$ and in farm II an average of $9.31 \mathrm{~kg}$, with the implantation of post-dipping the means of weight did not differ statistically and the means of weight were: in farm I. $4.91 \mathrm{~kg}$ and in farm II $10.01 \mathrm{~kg}$. Thus the percentage of milk weight increased, but the 30-day period was not enough to demonstrate higher production results, requiring a longer time of use of post-dipping for a new measurement, as stated by Lopes et al. [17], which evaluated the economic impact of mastitis in dairy cattle herds and found that the value related to the reduction in production per lactating cow caused by subclinical mastitis was $\mathrm{R} \$ 318.65$ (US\$ 141.50) and emphasized that prevention is an item that should receive great attention from technicians and cattle ranchers.

\section{CONCLUSION}

Post-dipping evaluation in this study contributes to the reduction of infections of the mammary gland, increases the production of milk per cow maintains the quality of the raw material increases the industrial yield of all the products benefited, and decreases the rich public health with foodborne illness.

\section{COMPETING INTERESTS}

Authors have declared that no competing interests exist.

\section{REFERENCES}

1. Faria MJM, Braga CASB, by Paula JR, André MCDPB, Vaz BG, by Carvalho TC, Romão W, from Costa HB, from Conceição EC. Antimicrobial activity of Copaifera spp. Against bacteria isolated from milk of cows with mastitis. Brazilian Animal Science. 2017;18:1-14.

2. Oliveira AA, Seixas L, Azevedo HC, Teixeira KM, McManus C, de Melo CB. Evaluation of the use of good practices in dairy cattle herds. Brazilian Journal of Veterinary Medicine. 2015;37(1):73-77.

3. Araújo BFO, Silva SGM, Silva JM, Cavalcanti Neto CC, Silva PCV, Montaldo YCM, Costa JHQ, Alves ESA, Santos TMC. Microbiological quality and somatic cells of in natura milk produced in Alagoas State, Brazil. Research, Society and Development. 2020;9(9).

4. Gonçalves JL, Tomazi T, Santos MV. Efficient milking routine for high quality milk production. Academic Journal of Animal Science. 2017;15:9-14. 
5. Ribeiro Júnior JC, Beloti V. Bovine mastitis and its impact on milk quality - literature review. Electronic Journal of Education and Science. 2012;2(2):1-12.

6. Siqueira RS. Food Microbiology Manual. National Center for Research on Agroindustrial Food Technology. Rio de Janeiro: EMBRAPA - CTAA, 1995.

7. Ferreira DF. Sisvar: a Guide for its Bootstrap procedures in multiple comparisons. Science and Agrotechnology. 2014;38(2):109-112.

8. Brazil. Ministry of Agriculture, Livestock and Supply. Normative Instruction No. 76, of November 30, 2018. (2018). Official Gazette of the Union. Brasília: MAPA. Available:http://www.in.gov.br/materia//asset_publisher/Kujrw0TZC2Mb/content/id /52750137/do1-2018-11-30-instrucaonormativa-n-76-de-26- de-November2018-52749894IN\%2076>. Accessed September, 20, 2021.

9. Coelho KO, Mesquita AJ, Machado PF, Lage ME, Meyer PM, Reis AP. The effect of somatic cell count on yield and physicochemical composition of Mozzarella cheese. Brazilian Archive of Veterinary Medicine and Animal Science. 2014;66(4): 1260-1268.

10. Zanlorenzi MTCF, Montanhini MTM. Evaluation of the Efficiency of Qualitative Chloride Testing for Investigation of Milk Adulteration. PUBVET. 2014;6(21):75-79.

11. Vargas DP, Nörnberg JL, Mello RO, Sheibler RB, Breda FC, Milani MP. Correlations between somatic cell count and physicochemical and microbiological parameters of milk quality. Brazilian Animal Science. 2014;15(4):473-483.

12. Barros AF, Alves ESA, Silva JM, Santos TMC. Diagnosis and etiology of subclinical mastitis in dairy goats. Agricultural Science. 2018;16:1-3.

13. Santana RCM, Zafalon LF, Brandão HM, Junior GAF, Pilon LE, Barioni Junior W, Giglioti R, Mosqueira VCF. Use of nanoparticulate antimicrobial for the treatment of subclinical mastitis in beef ewes in the dry period. Brazilian Veterinary Research. 2016;36(9):826-830.

14. Braz PH, Kuhn LS, Deboleto SGC, de Matos AT, Fraga TL. Behavior of Creactive protein in dairy cows compared to California Mastitis Test. PUBVET, 2017;11(9): 860-863.

15. Andreatta E, Oliveira CAF, Marques MC, Fernandes AM, Sanvido G, Gigante ML. Evaluation of yield and proteolysis of Minas fresh cheese produced with different levels of somatic cells: Preliminary Results. Brazilian Journal of Food Technology. 2006;9:71-74.

16. Ribas NP, Hartmann W, Monardes HG, de Andrade UVC. Total Milk Solids in Tank Samples in the States of Paraná. Brazilian Journal of Animal Science. 2004;33(6):2343-2350.

17. Lopes MA, Demeu FA, da Rocha CMBM, da Costa GM, Franco Neto A, dos Santos G. Evaluation of the economic impact of mastitis in dairy herds. Archives of the Biological Institute. 2012;79(4):477-483.

(C) 2021 Alves et al.; This is an Open Access article distributed under the terms of the Creative Commons Attribution License (http://creativecommons.org/licenses/by/4.0), which permits unrestricted use, distribution, and reproduction in any medium, provided the original work is properly cited.

\section{Peer-review history:}

The peer review history for this paper can be accessed here: https://www.sdiarticle5.com/review-history/77298 